\title{
Populasi
}

\section{International Migration and Aspirations among Young People: Who Desires to Migrate?}

\author{
Sri Purwatiningsih \\ Center for Population and Policy Studies, Universitas Gadjah Mada, Yogyakarta \\ Corresponding Author: Sri Purwatiningsih (email: athayarafif@yahoo.com)
}

\begin{abstract}
The dispatch of migrant workers from Indonesia is still quite high. Efforts to improve socioeconomic status are still motivated by high rates of migration. Children left by migrant parents experience a greater emotional burden due to parenting issues. This study attempts to examine the aspirations of children and adolescents left by migrant parents based on data from the Child Health and Migrant Parents in South East Asia (CHAMPSEA) study. Analytical descriptive was used to describe children's aspirations towards migrations on migrant and non-migrant households. This study found that children gave a bad perception when mothers had to migrate. Emotional closeness between children and mothers makes the children feel sad when being left by parents. However, once the children's desire to migrate, especially in the 'young adult' group of children is precisely high. Having seen by sex, boys have a higher desire to migrate than women.
\end{abstract}

Keywords: aspirations; youth migration; international migration

\section{Introduction}

Based on BNP2TKI data in 2016 2018 , the number of international migrations in Indonesia has increased. Data from BNP2TKI in 2018 recorded that 761,442 Indonesian migrant workers (PMI) worked abroad (http://www.bnp2tki.go.id). United Nations 2015 data shows that Indonesia is one of the top 10 countries in the Asia Pacific as a migrant sender. Migration is regarded as an effort to increase income which will be able to position oneself in a higher status in society (Sukamdi, 2007). Positioning oneself in a certain socio-economic environment is an important factor that encourages many people to go for working abroad. Some efforts to improve socio-economic status are factors that encourage someone to migrate. Therefore, many people from low-income groups are interested in migrating. Low income and lack of work are the main reasons they leave their hometown (Elbadawy, 2011). Lam and Yeoh (2019) stated that for many families in Southeast Asia, migration is a strategy to get an important livelihood.

The absence of parents due to migration will bring changes to the pattern of parenting, as well as will have an impact on the children left. In fact, the left children are a vulnerable group (Bakker, et al., 2009). Supervision or parenting patterns for children left by migrant parents will be replaced by the presence of blended family or step family (Bryant, 2005; 


\section{Sri Purwatiningsih}

Hugo, 2002). However, there is not much literature and research involving children, such as understanding the feelings and reactions of abandoned children although children are often a consideration in deciding whether the parents are going to migrate or not (Lam and Yeoh, 2019).

Purwatiningsih's (2016) study based on CHAMPSEA wave I data shows that the left children want to go abroad as their parents did. The environment where children live, which is dominated by many migration phenomena, has influenced children's mindset. Therefore, understanding the aspirations of children left by migrant parents is an interesting issue to observe. In the wave II study, children who were left by their migrant parents had turned into teenagers aged 17-19 years. Therefore, their aspirations regarding migration are likely to be more affected by many factors. This study will explore children's aspirations towards international migration based on data from CHAMPSEA (Child Health and Migrant Parents in South-East Asia) wave II. This study was focused on answering the following questions.

1. How do young people perceive international migration and work abroad?

2. What are the aspirations of young people towards international migration?

\section{Migration in Indonesia}

Indonesia has an interesting case for the study of youth migration issues. Indonesia is currently facing challenges in its human developmen related to the unequal distribution of the skilled youth population across regions (Malamassam, 2016). Also, migration has become a long history in Indonesia. Sending migrant workers abroad has become one of the ways to overcome domestic unemployment and improve local living standards (Sukamdi, 2008).

The Indonesian government is increasingly promoting labor migration as a development strategy to address national problems, such as poverty, unemployment, and underemployment, as well as encouraging capital flows from abroad through remittances (IOM 2010). The use of remittances as an emergency fund reserve for families can be seen as a migration benefit, as it allows families to have a social safety net (Hugo, 1995). Therefore, international migration and the remittances received by migrants are important aspects of the national economy. Remittances sent to areas of origin have also been able to improve household welfare.

In recent years, migration in Indonesia has also experienced the feminization of migration. Indonesia has become a major sender of women migrants to several countries (IOM, 2010). Data from BNP2TKI (2018) shows that it in 2018, 68 percent of migrant workers were women, while 32 percent were men. The high number of female migrant workers is a response to the need for unskilled workers that is still high (Sukamdi, 2007). However, the high number of migrant workers does not rule out the possibility that it will have a negative impact, both for the workers themselves and their families at home country.

International migration is a quite complex issue and includes many issues, meaning that it does not solely refer to the concept of "push and pull" power (Sukamdi, 2007). Besides, migration has a big impact to the families who have been left. When the parents do the migration, the household should be reset. This will then affect the welfare of both the children and the caretaker (Graham, et al., 2014). Several studies noted the impacts of international migration by parents towards their children (Bryant, 2005; Mc. Kenzie and Rapoport, 2007; and Antman, 2012). However, children's education or future is always the underlying reason said by most of the parents who decide to do the international migration (Lam and Yeoh, 2019). 


\section{Motivation to Migrate among Young People}

Youth groups are an integral part of contemporary migration flows. What characterizes migrants in Indonesia is that of dominated by young people in which $64.9 \%$ of the migrant population aged between 15 and 34 years (Sukamdi and Mujahid, 2015). The United Nations data also show that the migrant population is becoming younger. In 2000-2017, the average age of international migrants declined in Asia (United Nations, 2017). The Global Migration Group (GMG) notes that 12 percent of the current migration flows are young people aged 15-24 years (UNICEF, 2014). The report also notes that young people's motivation to migrate is often linked to the search for a decent livelihood due to THE lack of job opportunities.

Migration can be considered as an alternative strategy to get out of the poverty trap. Migration, with the income earned from it, also has a role in poverty alleviation, at least for the migrants' origin. In general, people can migrate since there are opportunities to do so, such as job opportunities and how to migrate. Regarding labor migration on a large scale, Indonesia has shown an increase in the diversity of labor mobility in terms of space and duration (Choon Yen et al., 2014). Limited employment in rural areas has encouraged job seekers to leave their villages. Besides, in the Indonesian context, labor migration has become a household investment strategy to gain more economic benefits (Knerr, in Choon Yen, et al. 2014).

The issue of lack of employment as a motivation to migrate is also raised by Minza (2012), that for young people, employment may be a more relevant indicator of perceptions about mobility among them. Moreover, Minza (2012) also suggested that groups of young people from middle class and simpler backgrounds hope that a better level of education will be a ticket for them from an informality in rural or urban areas to a better future through professional jobs.

Economic motivation is the main reason for moving (Malamassam, 2016). More specifically, migration is generally motivated by a desire to improve living standards, and migrants move to some places with better economic opportunities (Sukamdi and Mujahid, 2015). In general, the aspirations of young people for employment and living standards in the middle class are mitigated by their responsibilities towards their families and difficulties in making social connections needed to access jobs and opportunities (Naafs, 2017).

In addition to economic motivation, a person migrates since he has friends or family who are already working abroad. Migrant networks are also an important factor in influencing one's decision to migrate (Sukamdi, 2007). Social networking is a form of social capital that a person can use to access various types of financial capital, such as working abroad (Massey, et al, 1998 in Haug, 2008). Social networks and the people involved in them also have an influence on the decision to migrate since the network will provide access to migration routes and work security at the destination (Ananta and Arifin, 2004).

The social network factor is also emphasized by Elbadawy (2011) which indicates that having a migrant in a social network is a key factor in growing migration aspirations. Based on his study that was conducted in Egypt, 55 percent of the young people aspiring to migrate have friends or relatives who are migrants as well. Meanwhile, Choon Yen, et al (2014) explained that the impact of having a network at the destination is very high and significantly increases the possibility of migrating.

Migration networks may be defined as interpersonal relationships in which migrants interact with their families or friends. The social network will provide information as 
well as provide protection or assistance if needed (Haug, 2008). In the context of the migration chain process model, the order of migration within a household or network is very crucial. The reciprocal influence caused by one family member who migrates shows that everyone contributes reciprocally to the other families.

Meanwhile, having a family with migration experience is also one of the socio-economic factors that influence young people to migrate (Elder et al, 1996). The migration experience among young people is largely part of the migration performed by families or parents. Furthermore, Elder, et al (1996) explained that the environment and cultural background of the people of origin can influence the decision of young people to migrate. For this reason, the phenomenon of intergenerational migration occurs in some areas of Indonesia since migration has become a long history.

\section{Method}

This study is the result of the CHAMPSEA wave I 2008 and the CHAMPSEA wave II 2016 studies which are longitudinal studies. This study was conducted in West Java (Sukabumi and Tasikmalaya districts) and East Java (Ponorogo and Tulungagung districts). This study was focused on data on children with a sample of 444 children in the young-adult category (aged $17-19$ years) and 470 children in the middle-child category (aged $11-13$ years) from migrant and nonmigrant households.
The analysis used in this study is descriptive analytic to describe the aspirations of children towards migration in migrant and non-migrant households. It was conducted on selected variables related to children's perceptions of migration. The variables used for analysis include children's perceptions about parents working abroad, children's feelings about parents leaving, and parents' desire to work abroad.

\section{Results and Discussion}

Children's Perceptions on Parents Working Abroad

International labor migration may have an impact on household welfare. Remittances generated by migrants have a contribution to household economic welfare. This is in line with Suyanto's study (2018) which revealed that remittances are used to meet daily needs, pay children's education costs, buy land and build houses, establish productive businesses and buy secondary goods. Although migration has a positive impact on the economy, children's perceptions about having parents working abroad are quite diverse. This may happen because children are not asked for their opinion when their parents are going to work abroad, yet children are only notified if their parents (either father or mother) are going to work abroad. CHAMPSEA data also shows that more than 80 percent of children said they were told if their father or mother would work abroad. 


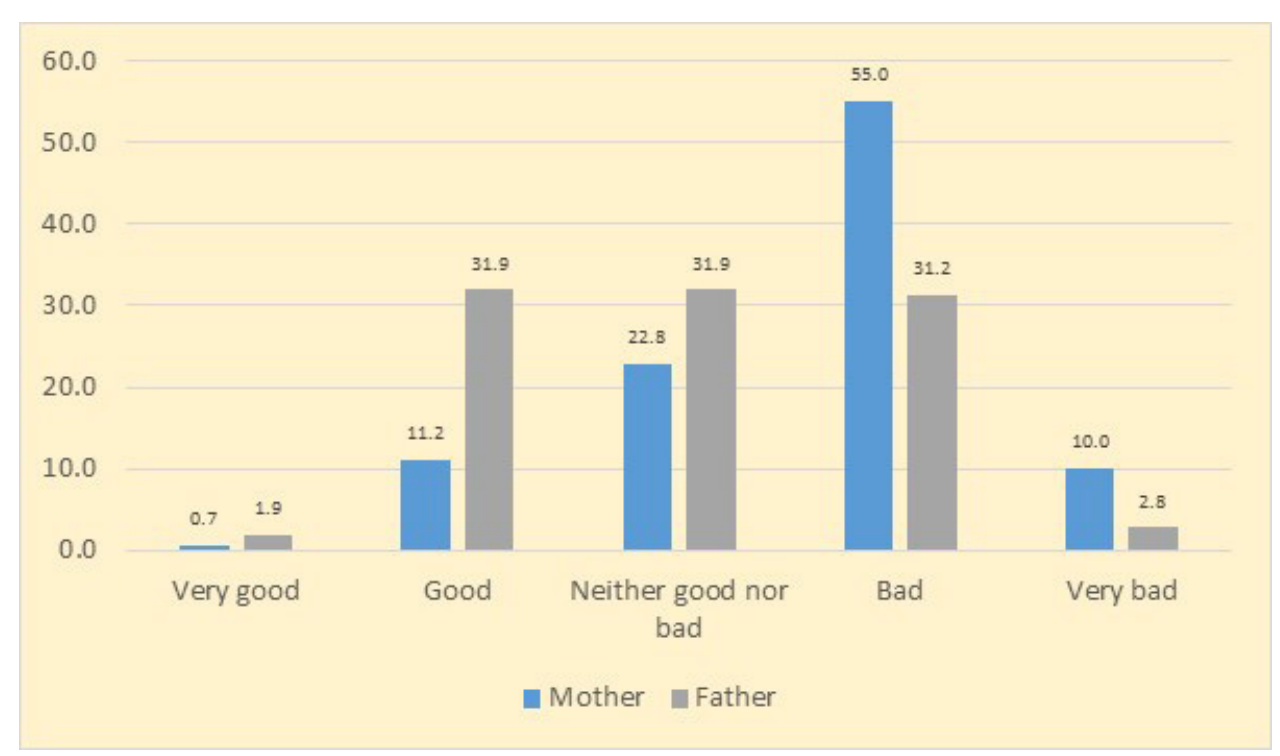

Source: CHAMPSEA Data, 2016

Figure 1. Children's Perceptions on Parents Working Abroad

Most of the bad perceptions are given to mothers who work abroad (i.e., more than 55 percent of children who say their mothers work abroad are perceived as bad). Meanwhile, children's perceptions on having father working abroad shows almost the same assessment, either they have good perceptions $(31.93 \%)$, moderate $(31.93 \%)$, or bad perceptions (31.24\%). Meanwhile, children's perception on having mother working abroad is perceived as very bad perceptions (i.e., 10.02 percent) and good perceptions (i.e., 11.19 percent). This shows that the children are as if unwilling to be left by their mothers who have to work abroad, because more than 55 percent of children think that this is not good for their children.

Hoang and Yeoh (2012),explained that the absence of mothers as a result of transnational migration brings about a huge emotional challenge in terms of child care. As a result, the children feel more lost if their mothers leave them for working abroad compared to fathers who go for working abroad. Also, psychologically, there is an emotional cost of women's migration which is closely related to concerns about the dryness of care (Hochschild, 2002 in Hoang and Yeoh (2012)). This is as a result of the father who is unable to understand the emotional and psychological needs of the child, so he is unable to cope with the psychological burden of the child due to the abandonment of his working mother (BNP2TKI, 2014).

Furthermore, if the children's perceptions are broken down by migrant status of parents and category of child, there are also varying perceptions. Most of the middle-class children in various categories of migrant families showed good perceptions for having fathers working abroad. Many children from families of migrant fathers showed good perceptions as well (46\%), while those from families whose mothers are migrants, shoed good perceptions (38.2\%) on having fathers working abroad. Many children from non-migrant families also showed good perceptions on having fathers working abroad. Meanwhile, those from families with both parents as migrants said that it is normal or not good or bad $(46.2 \%)$, while those who said it is good were $30.8 \%$. 


\section{Migrant Fathers}

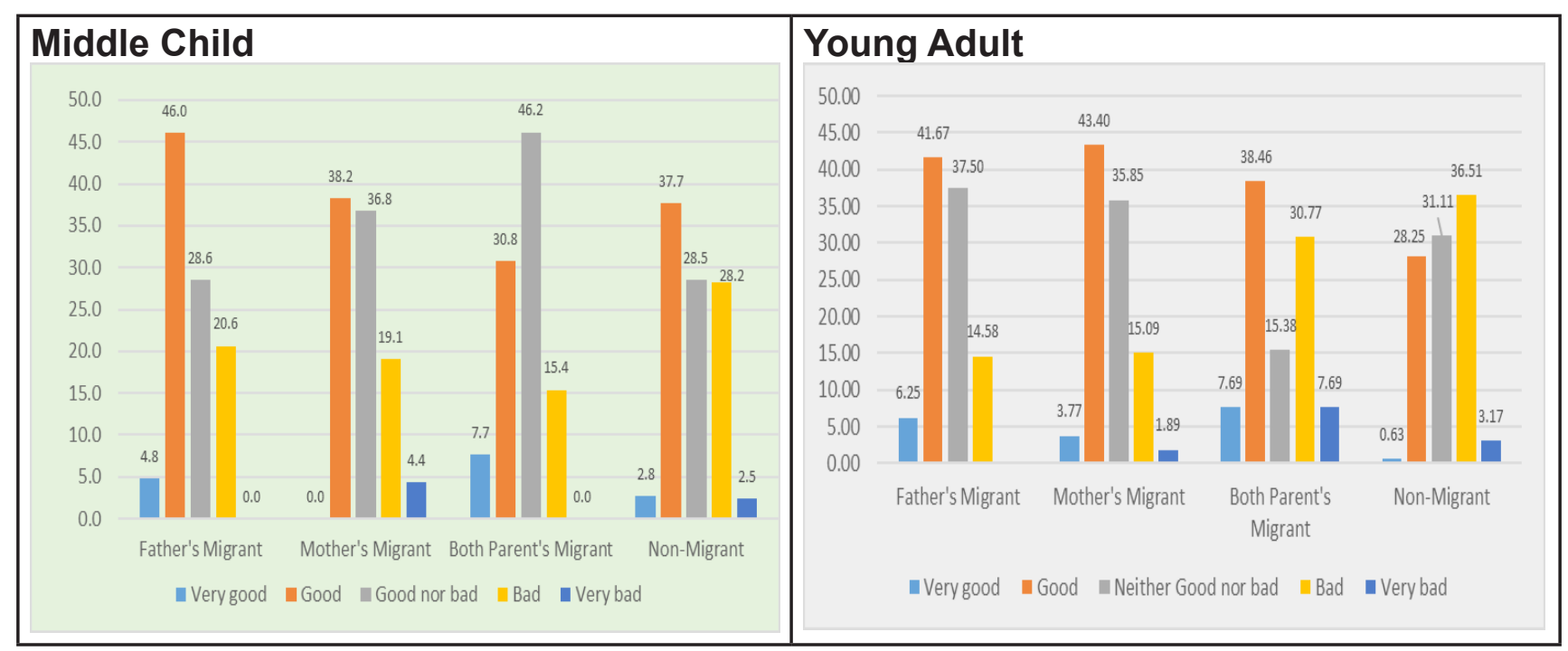

\section{Migrant Mothers}

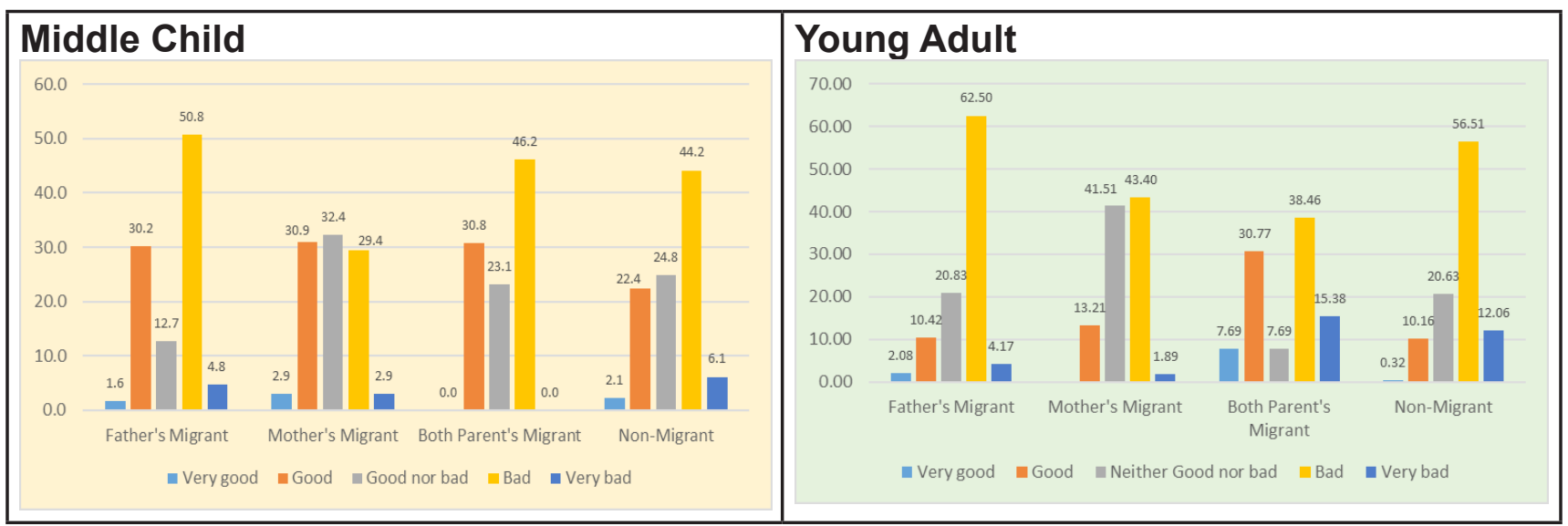

Source: CHAMPSEA Data, 2016

Figure 2. Children's Perceptions on Parents Working Abroad by Parents' Migration Status

Meanwhile, in the "young-adult" group, good perceptions of fathers working abroad were said by children in the household category of migrant fathers $(41.67 \%)$, migrant mothers $(43.4 \%)$, and the category of both parents are migrants $(34.46 \%)$. Meanwhile, children from the nonmigrant household category are more likely to show bad perceptions on having fathers working abroad (36.51\%). In the second category of households, there are also many migrant parents who had bad perceptions $(30.77 \%)$. This indicates that children from families exposed to migration have more favorable perceptions on having fathers working abroad.

Meanwhile, a different perception was expressed by children towards their mothers who work abroad. Both 'middle child' and 'young adult' groups of children 
were more likely to give a bad perception if their mothers had to work abroad. Also, if it is seen by category of migrant household, almost all household from all categories gave a bad perception for mothers who work abroad. It is only the middle child group of migrant mother households who gave a lower-bad perception (29.4\%) and more gave moderate perceptions (32.4\%). The results of this study show similarities with previous studies, that the children left by their parents due to migration said that their daily lives became more difficult when their mothers migrated. They prefered their fathers who migrate to their mothers or both parents migrate at the same time. This complete absence of parents may make the child feel heavy, but if there is still a mother at home, the child will still feel safe (Purwatiningsih, 2016). This is also in line with Lam and Yeoh (2019) that children feel stable when their father migrates to earn a living, while there is still a mother who plays a role in parenting.
However, it turns out that children in a family whose father migrate abroad while there is mother at home for child care is identified as having poor mental health (Graham et.al., 2014).

\section{Respons to Parental Migration}

Most of the responses to the departure of their parents due to migration said they were sad because they missed them. However, most of those who said they were sad because they missed were from the 'young adult' group for the departure of their mother $(71.2 \%)$, while the 'middle child' group of children expressed feelings of sadness because they missed their mother who went abroad were $59.76 \%$. The sadness due to longing to be left by father was also widely expressed by children in the 'young adult' group $(50.8 \%$ ), while the rest (the 'middle child' category) were $39.47 \%$.

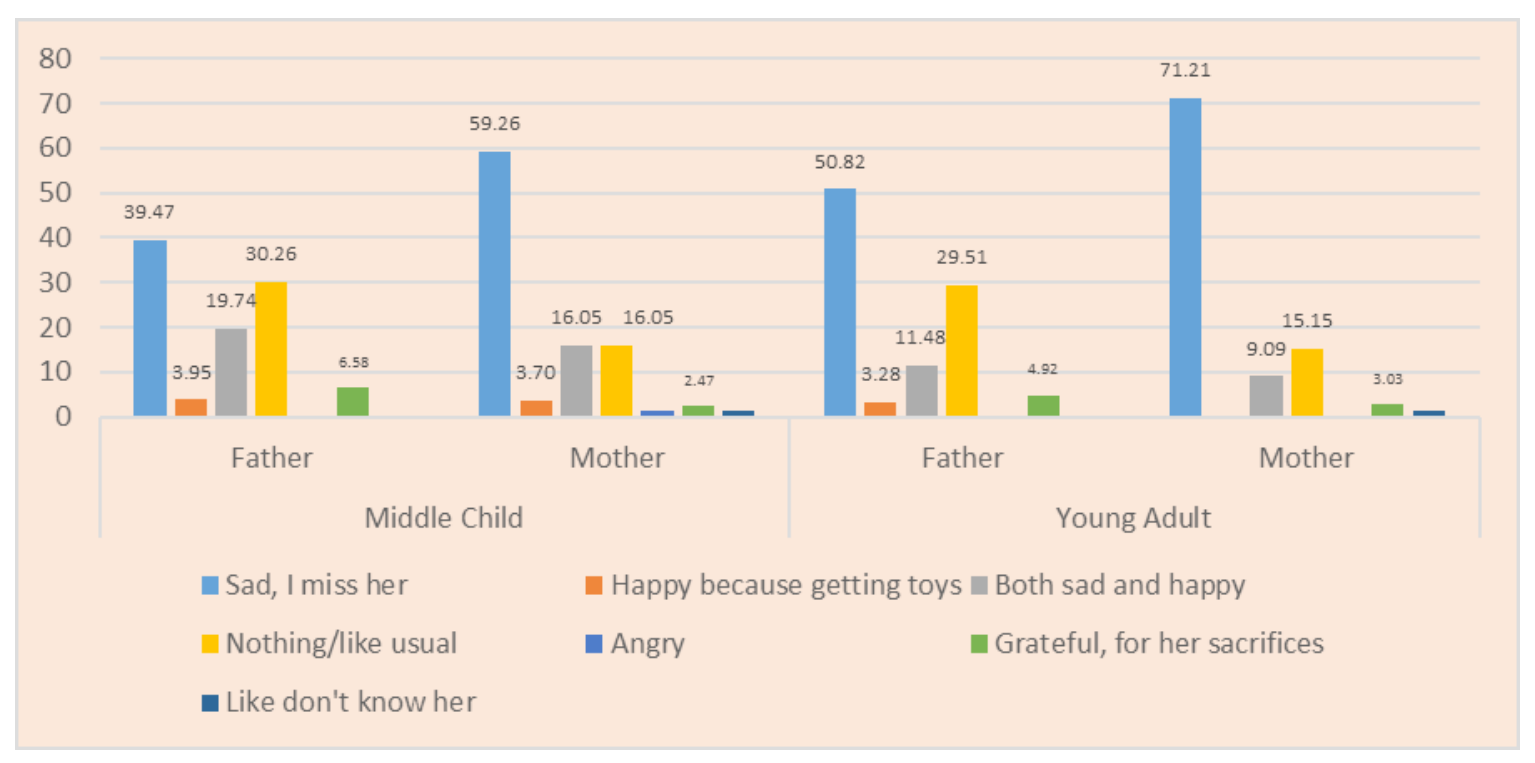

Source: CHAMPSEA Data, 2016

Figure 3. Children's Feeling about Parents' Migration 


\section{Sri Purwatiningsih}

The 'middle child' group of children who expressed a sad and ordinary response were almost the same (i.e., $30.26 \%$ of them said that it is normal for their father to leave and migrate abroad). Also, those from the 'young adult' group were quite a lot who said it is normal if their father left them to migrate abroad for working (29.51\%). They show less sadness when their father migrated due to the lack of emotional connection between father and children. This is because the migrant father tend to only communicate with their family, whereas the migrant mothers will keep an intimate relationship with their children by making regular communication (Hoang and Yeoh, 2012).

Children's sadness when their mother is not at home is regarded as a psychological expression of children who are emotionally closer to their mothers. The care for children who has been left by migrant mother is taken over by their father or grandmother. Although the role of the father or grandmother is only a "supplement" in parenting. However, in the case of migration, they become a substitute caregiver (Setiawan et al., 2018). Even children whose mother has left them for migration do not get enough attention to social and psychological aspects, even though they are financially fulfilled. There are several things that are often forgotten behind the overflow of money from the migrating parents. Children lose their right to get complete love from both parents (Napsiah, 2017).

Meanwhile, the reason for parents migrating to work abroad is mostly (more than $50 \%$ ) due to education, both for migrant mothers and migrant fathers. It shows the same results as that of CHAMPSEA wave 1 which also confirm that most of the reasons for migrating are also for children's education. The results are similar to the results of a study conducted by Wirastyani et al. (2016) that the use of remittances from international migration is used for children's education. Children's education is one of the investments for the success of children from migrant families.

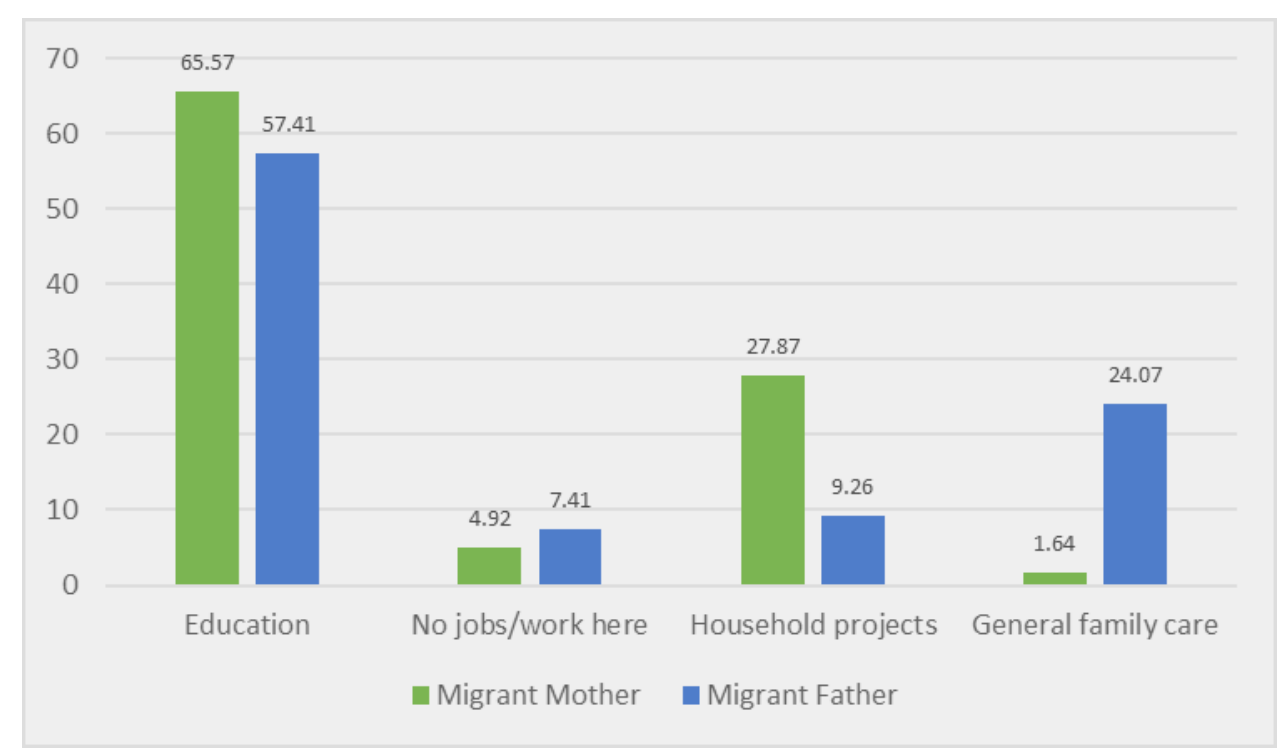

Source: CHAMPSEA Data, 2016

Figure 4. Parents' Reasons to Migrate 
Another reason why parents migrate to work abroad is for household projects and family care. What is meant by household project is generally to repair the house, which is the reason for $27.87 \%$ of migrant mothers. The houses of migrants' families in the study area were better than those of nonmigrant families. Meanwhile, among migrant fathers, another reason for going to migrate apart from children's education is for family care $(24.07 \%)$. The result is in line with the results of Suyanto's study (2018), showing that remittances are used to meet daily needs, children's education costs, buy land, and build houses.

\section{The Migrants are Aspired to Migrate}

Groups of young people want to migrate because of the motivation to improve their economy (Malamassam, 2016). CHAMPSEA wave 2 data shows that $44.26 \%$ of children in the 'middle child' category and $38 \%$ of children in the 'young adult' category intend to go abroad to work. However, if the data is broken down by gender, both the 'middle child' and 'young adult' groups are higher in men who have the desire to go abroad to work. This is in contrast to the results of Malamassam (2016), which is that women's aspirations to migrate are higher.

Job opportunities for men are more varied compared to women, which are still more in the domestic sector. So that the opportunities for men to work abroad are greater. National Agency for the Placement and Protection of Indonesian Workers (BNP2TKI) shows that the opportunities for men to work abroad are quite varied and the data on male migrant workers is also more than that of women (BNP2TKI, 2017).

More job opportunities for men are also present due to restrictions on the dispatch of formal workers compared to non-formal since 2009, which were implemented to limit the dispatch of informal workers to Malaysia. Besides, the Decree of Minister of Manpower of the Republic of Indonesia Number 1/2015 concerning Positions that can be occupied by Indonesian Workers Abroad for Domestic Work. The restriction aims to provide protection for Indonesian migrant workers abroad. This has an impact on reducing the number of female migrant workers and reducing the number of migrant workers with low education.

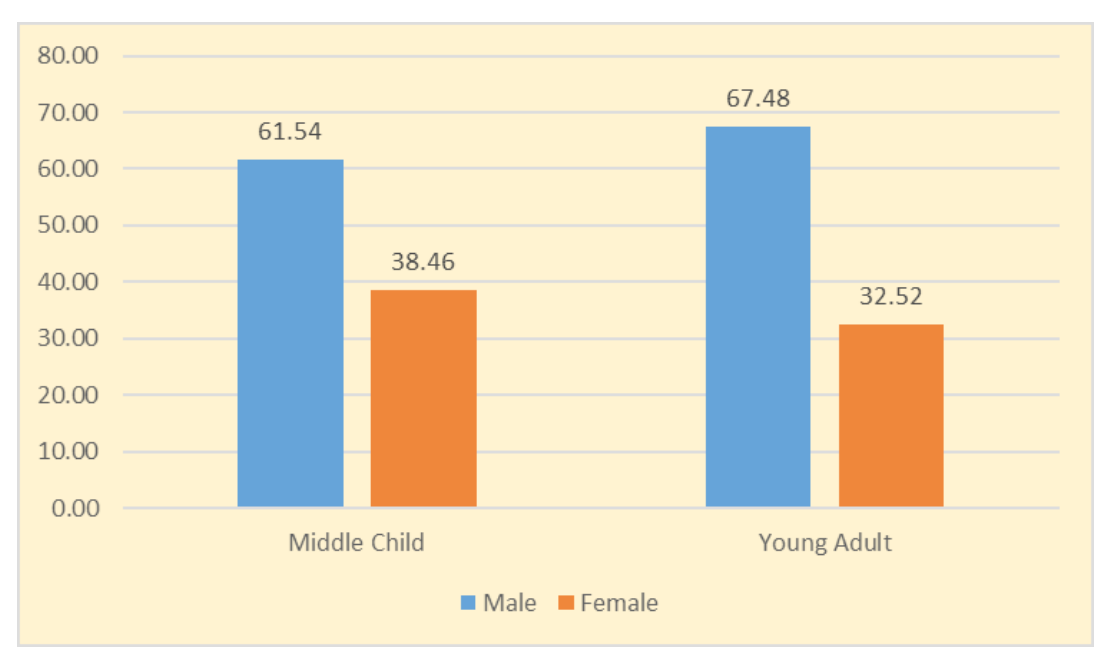

Source: CHAMPSEA Data, 2016

Figure 5. Children Aspiring to Migrate by Gender 


\section{Sri Purwatiningsih}

Based on the migration status of parents, it turns out that the group of young adults from families with both parents as migrants is the group with the highest desire to migrate abroad $(76.92 \%)$. The desire to migrate in this group is very high, even it tends to be the highest among other groups. In fact, this group is a group that had an experience of being left by both parents for migrating and they obtained parenting with other families. However, they had a high desire to migrate instead.

The finding is interesting since this group psychologically becomes the most affected by the absence of their parents in terms of care. Strong economic motivation has encouraged young people to migrate.
However, there is a desire for families to stay together regardless of the economic situation and this is emphasized a lot by parents when asking their children when they growup and want to migrate (Lam and Yeoh, 2019).

This economic motivation cannot be separated from the welfare level experienced by migrant households, thus encouraging children to migrate as their parents have done. The welfare level of migrant households is presented in Figure. The most households with both migrant parents are shown in quintile 5 , followed by households with migrant fathers. Meanwhile, non-migrant households have low welfare level and most of them are in quintile 1-2.

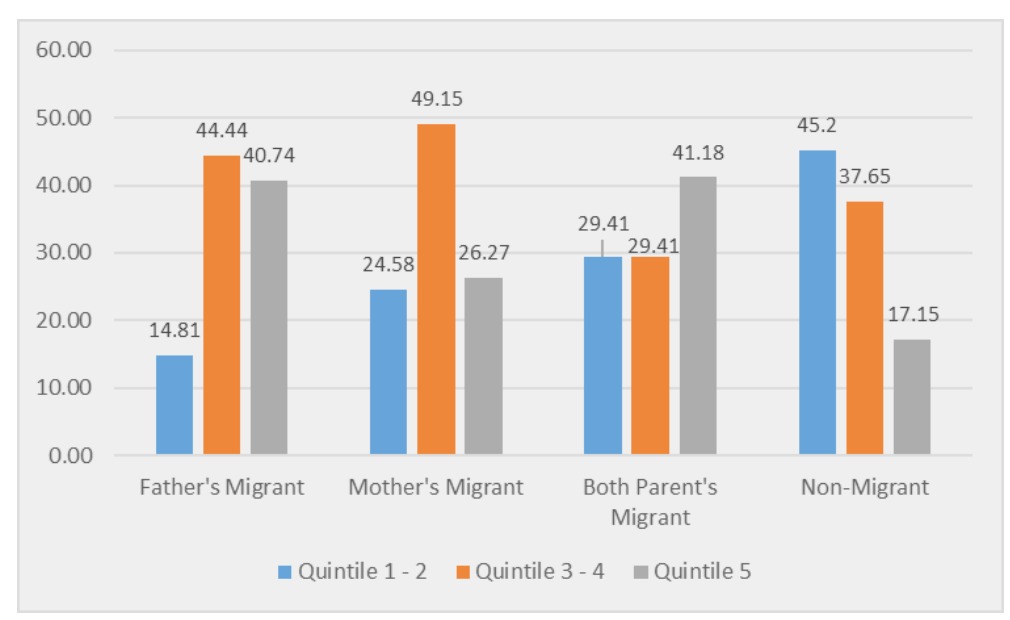

Source: CHAMPSEA Data, 2016

Figure 6. Migrant Household Welfare Index

Meanwhile, in the 'middle child' group from families whose both parents are migrants, it was only $30.77 \%$ who had the desire to migrate. This is probably due to the fact that children who are younger have a strong emotional bond with their parents, so the sadness of being left by their parents has an impact on the aspirations of the children. Parental employment contracts in the destination country often force parents to determine the frequency of return visits to their homes due to contractual and financial reasons, and thus, it has negative consequences for the abandoned child (Graham et al., 2015). 


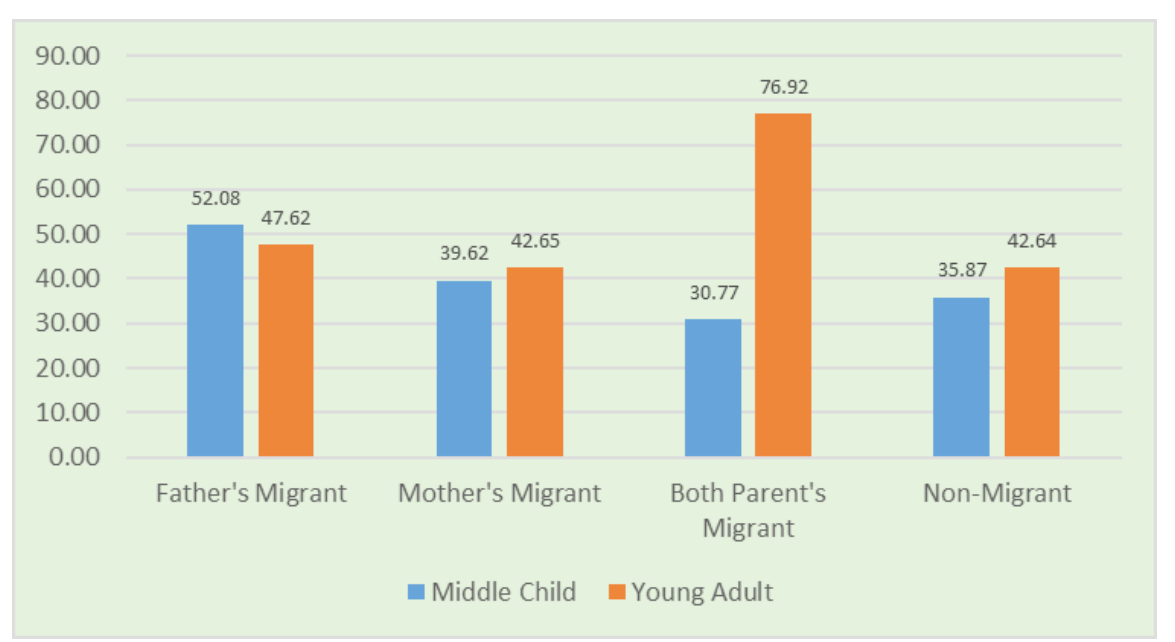

Source: CHAMPSEA Data, 2016

Figure 7. Children's Desire to Migrate by Parents' Migration Status

In children with family backgrounds with migrant fathers, the desire to migrate between the 'middle child' and 'young adult' groups was almost the same (i.e., $52.08 \%$ and $47.62 \%$, respectively). This indicates that almost half of the respondents with a family background of having migrant father wished to become a migrant, but the sadness of being left by the migrant father is lower than that of with the migrating mother. Therefore, this also has implications for the lower desire to migrate among children from the family background of migrant mothers. Children's desire to migrate in children with family backgrounds of migrant mothers is almost the same as the desire to migrate in children with non-migrant family background.

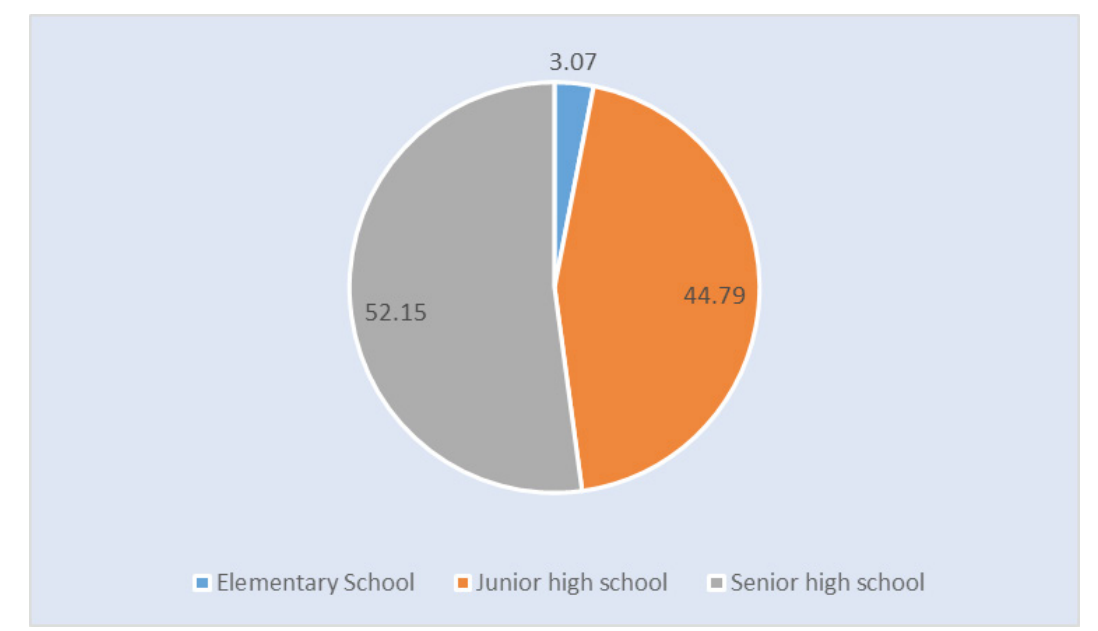

Source: CHAMPSEA Data, 2016

Figure 8. Children's Desire to Migrate by Educational Background 


\section{Sri Purwatiningsih}

There is a higher desire to migrate in groups with higher educational background. Fewer children with lower educational background are willing to migrate. Cross tabulation of education achieved with the desire to migrate was performed in the 'young adults' group of children aged 17-19 years, so many of them have accomplished their study. Only $3.07 \%$ of teenagers with educational background of primary school have the desire to migrate. Meanwhile, $44.79 \%$ of the teenagers with educational background of junior high school have the desire to migrate, while those with educational background of high school are $52.15 \%$. This is in line with the results of the Malamassam's study (2016) which reveals that the probability of migrating young people in Indonesia is higher in children with higher education.

The results of this study indicate an anomaly regarding the desire to migrate. However, based on Abdullah's elaboration (2002), this assumption arises because the understanding on migration tends so far to simplify the facts. Classical migration concepts seem unsuitable to be applied in international migration studies. Migration is not only seen because of the driving force and attraction of migration, which if quoting the Faturochman's opinion (2002), migration should be understood as an event that can be observed and measured. Migration should be understood as a behavior that emphasizes the presence of a process, not only seen as a response to certain conditions (Sukamdi, 2007).

In migration enclaves, in general, migration has a long history that is passed down from generation to generation so that the culture of migration has become daily life for the community. However, a change in the trend of migrant destination countries may occur. ILO data shows that until 2002, the trend of the destination countries for migrants was Malaysia and Saudi Arabia (Sukamdi, 2007). However, BP2MI data (2020) shows a shift in the destination country. Saudi Arabia is no longer a destination for migrants, but it has shifted to Taiwan and Hong Kong. This cannot be separated from the moratorium on migrant workers dispatch to Middle Eastern countries since 2015. Also, there is a conversion of non-formal to formal workers, that conversion is carried out in several ways including by increasing the employment opportunities of Indonesian Migrant Workers (TKI) in the formal sector as well as restrictions and terminations (moratorium) on the TKI dispatch in the non-formal sector (Triyani, 2016). Young groups in migrant areas will try to improve their educational status with the restrictions and moratoriums, so they can work abroad and earn better incomes.

\section{Conclusion}

This study aims to find out the aspirations of young people towards international migration. Based on CHAMPSEA Wave II data, the respondents were the 'middle child' group of children aged 11-13 years and young adults aged 17-19 years. This study was conducted in migrant enclaves in West Java and East Java. Migration has even been hereditary for several generations in Ponorogo, East Java. Migrants' environment will affect children's perception on migration.

The results of this study show that children mostly gave a bad perception for mothers who migrate to work abroad, while fathers who migrate were generally considered good. This is because the absence of the mother has a big emotional impact on child care.

Meanwhile, most of the children's responses to their parents' leaving due to migrating abroad show that they were sad because they missed them, and this response was mostly expressed by children when their mothers left for migration. Meanwhile, the children's responses to their father's migration show that it was normal for their father to leave them for migrating abroad. 
The reason the parents migrated to work abroad is mostly due to education, both for migrant mothers and migrant fathers. Education is a crucial indicator in terms of the socio-economic community. Moreover, education is considered as one of the investments for the children's success, especially for migrants' families. Despite education, the parents decided to migrate for household projects, such as home renovation.

The results confirms that the aspirations of young people to migrate are quite high and it is the economic motivation that usually becomes the reason why they are still willing to go for working abroad. Meanwhile, if the aspirations to migrate is seen by gender, there are more groups of men who have a greater desire to migrate, both in the 'middle child' and 'young adult' group of children. Boys' aspiration to migrate is quite high since it is related to greater job opportunities for men working abroad than women due to policies that limit the departure of workers to work abroad.

If the aspirations towards migration are broken down based on household background, the 'young adult' group of children with migrant parents (both the father and the mother) have the greatest desire to migrate. Meanwhile, based on the level of education, the desire to migrate is higher in the group of young people with a higher educational background. This population group needs more attention due to the high number of aspirations of young people regarding the desire to migrate for working abroad. The attention that can be given is by improving their education and skills so that once they work abroad, they may get into the formal employment sector that requires certain skills.

\section{References}

Abdullah, Irwan. 2002. "Studi Mobilitas Penduduk: Antara Masa Lalu dan Masa Depan" in Tukiran, et.al (eds), Mobilitas Penduduk: Tinjauan Lintas Disiplin. Yogyakarta: Pusat Studi Kependudukan dan Kebijakan UGM: 9 - 22.

Ananta, Aris dan Arifin, Evi Nurvidya. 2004. International Migration in Southeast Asia. Singapore: ISEAS Publications.

Antman, Fransisca M. 2012. "The Impact of Migration on Family Left Behind" dalam IZA Discussion Paper No. 6374, Februari 2012, The Institute for the Study of Labor, Bonn.

Bakker, Caroline, Martina Elings-Pels dan Michele Reis. 2009. Impact of Migration on Children in the Caribbean. UNICEF Office for Barbados and Eastern Caribbean.

BNP2TKI. 2014. "Eksplorasi Masalah Kesejahteraan Dan Perlindungan Anak Pekerja Migran (Studi di Kabupaten Indramayu, Provinsi Jawa Barat)" dalam http://www.bnp2tki.go.id/uploads/data/ data_11-03-2014_091712_T.A_2013_ EKS PLORAS I_MA SA L A H KESEJAHTERAAN_DAN PERLINDUNGAN_ANAK_PËKERJA_MIGRAN_(Studi_di_Kabupaten_ Indramayu,_Provinsi_Jawa_Barat).pdf akses 10 April 2019.

BNP2TKI. 2017. "Perbedaan Upah, Alasan Orang Bekerja ke Luar Negeri”, dimuat dalam http://www.bnp2tki.go.id/ read/12371/Perbedan-Upah-AlasanOrang-Bermigrasi-Ke-Luar-Negeri akses 6 April 2019.

BP2MI. 2020. Analisis Data Penempatan Pekerja Migran Indonesia Tahun 2015 2019. Pusat Penelitian, Pengembangan dan Informasi Badan Perlindungan Pekerja Migran Indonesia. 
Bryant, John. 2005. "Children of International Migrants in Indonesia, Thailand, and The Philippines: A Review of Evidence and Policies". UNICEF, Innocenti Working Paper.

Choon Yen, Khoo, dkk. 2014. "Gendered Migration Patterns, Processes and Outcomes: Results from a Household Survey in Ponorogo, Indonesia". Migrating Out of Poverty Research Programme Consortium, Working Paper 22, October 2014.

Elbadawy, Asmaa. 2011. MigrationAspirations Among Young People In Egypt: Who Desires To Migrate?, Working Paper published by The Economic Research Forum (ERF), Egypt.

Faturochman, 2002. "Nasib Migran dan Dominasi Konsep-Konsep Migrasi Internasional" in Tukiran, et.al (eds), Mobilitas Penduduk: Tinjauan Lintas Disiplin. Yogyakarta: Pusat Studi Kependudukan dan Kebijakan UGM: 23 -34 .

Graham, Elspeth, Jordan, Lucy P, dan Yeoh, Brenda S.A. 2015. "Parental migration and the mental health of those who stay behind to care for children in South-East Asia" in Social Science \& Medicine, 132: $225-235$.

Haug, Sonja. 2008. "Migration Networks and Migration Decision-Making" in Journal of Ethnic and Migration Studies, 34:4, 585 $-605$.

Hoang, Lan Anh, and Yeoh, Brenda S.A. 2014. "Sustaining Families across Transnational Spaces: Vietnamese Migrant Parents and their Left-Behind Children" in Asian Studies Review, September 2012, Vol. 36, pp. 307-325.

Hugo, Graeme. 1995. "International labor migration and the family: Some observations from Indonesia", Asian and Pacific Migration Journal, 4(2-3), 273301.
Hugo, Graeme. 2002. "Effects of International Migration on the Family in Indonesia" in Asian and Pacific Migration Journal, Vol. 11, No. 1.

International Organisation for Migration (IOM). 2010. Migrasi Tenaga Kerja dari Indonesia: Gambaran Umum Migrasi Tenaga Kerja Indonesia di Beberapa Negara Tujuan di Asia dan Timur Tengah. IOM, Jakarta

Lam, Theodora dan Yeoh, Brenda S.A. 2019. "Parental migration and disruptions in everyday life: Reactions of left-behind children in Southeast Asia" dalam Journal of Ethnic and Migration Studies, DOI: 10.1080/1369183X.2018.1547022: 1-20.

Malamassam, Meirina Ayumi. 2016. "Youth Migration in Indonesia: Decision to Move and to Choose Destination Areas" in Indonesian Journal of Geography, 48(1), June 2016, 61 - 71.

Mc. Kenzie, David dan Hillel Rapoport. 2007. "Network effects and the dynamics of migration and inequality: Theory and evidence from Mexico" dalam Journal of Development Economics, Vol 84, 1-24.

Minza, Wenty Marina. 2012. "Young Migrants and Education-to-Work Transitions in Pontianak, West Kalimantan" in The Asia Pacific Journal of Anthropology, 13(1), 64-75.

Napsiah. 2017. "Anak Mendambakan Orangtua yang Utuh: Resensi Buku" in Jurnal Sosiologi Reflektif, Volume 12, No. 1, Oktober 2017, 171 - 178.

Purwatiningsih, Sri. 2016. "Respon Anak-Anak Migran terhadap Migrasi Internasional di Perdesaan Ponorogo" in Populasi 24 Nomor 1, 57-71.

Setiawan, Hari Harjanto, et.al. 2018. Anak Pekerja Migran Perempuan dan Tantangan Bonus Demografi. Jakarta: Pusat Penelitian dan Pengembangan Kesejahteraan Sosial, Kementerian Sosial RI. 
Sukamdi. 2007. "Memahami Migrasi Pekerja Indonesia ke Luar Negeri" in Populasi, 18(2), $115-128$.

Sukamdi, 2008. "International Migration in Indonesia" dalam Asian and Pacific Migration Journal, Vol. 17, No. 3-4, 325334.

Sukamdi and Mujahid, G. 2015. UNFPA Indonesia Monograph Series: No.3, Internal Migration in Indonesia. UNFPA Indonesia Monograph Series. [online] Jakarta: UNFPA. Available at: http:// indonesia.unfpa.org/en/publications/ monograph-series-no-3-internalmigration-indonesia.

Suyanto. 2018. "Pemanfaatan Remitan Ekonomi dan Ketergantungan Migran Kembali Bekerja di Luar Negeri" in Endogami: Jurnal IImiah Kajian Antropologi Vol. 2 No. 1, 30-37.

Triyani, Teni. 2016. "Kebijakan Konversi TKI Non-Formal Ke TKI Formal sebagai Upaya Perlindungan Pemerintah Ditinjau dari Perspektif Hukum Ekonomi Pancasila" in Selisik Vol 2 No 2, Desember 2016, 1-16.

Unicef. 2014. Migration and Youth: Challenges and Opportunity. The Global Migration Group by the United Nations Children's Fund

United Nations, Department of Economic and Social Affairs, Population Division. 2017. International Migration Report 2017: Highlights (ST/ESA/SER.A/404).

Wirastyani, Ratna., Kanto, Sanggar., dan Siahaan, Hotman M. 2016. "Migrasi Internasional dan Pemanfaatan Remitansi Dalam Rangka Pengentasan Kemiskinan (Kasus di Desa Clumprit Kecamatan Pagelaran Kabupaten Malang)" in Wacana Vol. 19, No. 3, 138147. 